\title{
DAMPAK KONVERSI LAHAN PERTANIAN TERHADAP KONDISI SOSIAL EKONOMI PETANI \\ (Studi Kasus: Jalur Pantura Kecamatan Pamanukan Kabupaten Subang)
}

\author{
Oleh: Linda Dwi Rohmadiani
}

\begin{abstract}
Abstrak
Penelitian ini bertujuan untuk menjelaskan dampak konversi lahan pertanian terhadap kondisi sosial ekonomi petani dari aspek struktur mata pencaharian, kepemilikan lahan pertanian, dan migrasi. Metode yang digunakan adalah metode deskriptif dengan menggunakan pendekatan kualitatif dan kuantitatif.Trend konversi lahan di wilayah studi dari tahun 1997 ke tahun 2006 berupa berkurangnya sawah sebesar 34,48\%, tambak sebesar 2,75\%, kebun campuran sebesar 2,03\%, dan hutan sebesar 0,2\%. Faktor yang mempengaruhi perubahan penggunaan lahan adalah arah kebijakan pengembangan wilayah Kecamatan Pamanukan. Dampak dari konversi lahan pertanian adalah perubahan struktur mata pencaharian dimana semakin meningkatnya penduduk bekerja di sektor sekunder dan tersier, semakin ditinggalkannya sektor mata pencaharian primer yang dulunya merupakan sektor dominan, dan semakin banyak penduduk yang memiliki pekerjaan tambahan sebagai pedagang, buruh dan TKW. Perubahan luas kepemilikan lahan pertanian dimana semakin banyak jumlah petani non pemilik lahan pertanian dibandingkan petani pemilik lahan dengan perbandingan $5: 1$. Penyusutan lahan pertanian juga menyebabkan 17,89\% petani berubah mata pencaharian ke sektor sekunder ataupun tersier, dan peningkatan migrasi keluar yang dilakukan oleh keluarga petani sebesar 41,05\%. Jumlah migrasi masuk semakin meningkat dari tahun ke tahun seiring dengan konversi lahan pertanian, selain itu konversi lahan juga mempengaruhi jumlah migrasi keluar.
\end{abstract}

Kata kunci: dampak, konversi lahan pertanian, kondisi sosial ekonomi petani

\section{PENDAHULUAN}

Kecamatan Pamanukan merupakan salah satu kecamatan yang dilalui Jalur Pantura Pulau Jawa yang menghubungkan Jakarta (Pusat Kegiatan Nasional/ PKN) Cirebon (Pusat Kegiatan Nasional/ PKN). Secara relatif dalam konstelasi wilayah Kabupaten Subang, Kecamatan Pamanukan adalah kecamatan terbesar kedua setelah Kecamatan Subang baik dari luas wilayah, jumlah penduduk ataupun kelengkapan sarana dan prasarana sosial ekonomi. Menurut Rencana Tata Ruang Wilayah Propinsi Jawa Barat, Kecamatan Pamanukan merupakan wilayah pantai utara yang diperuntukkan untuk kawasan lahan basah (Revisi RTRW Kab.Subang Tahun 2002 2012, hal. II.1). Rencana hirarki kota-kota berdasarkan Revisi RTRW Kabupaten Subang Tahun 2002-2012 dalam, Kecamatan Pamanukan merupakan kota hirarki I dengan fungsi utama sebagai pusat pertumbuhan utama dan sebagai gerbang perdagangan ke luar wilayah kabupaten. Sedangkan dalam rencana pembagian fungsi kota-kota, Kota Pamanukan berfungsi sebagai pusat pertumbuhan dan pusat pelayanan Wilayah Pengembangan II, pusat koleksi dan distribusi hasil pertanian, perikanan dan kebutuhan pokok. Wilayah Pengembangan II meliputi Kota Pamanukan (sebagai pusat pelayanan
Wilayah Pengembangan II), Kota Ciasem, Kota Legonkulon, Kota Blanakan, Kota Pusakanagara, Kota Binong, dan Kota Compreng. Kecamatan Pamanukan juga merupakan pusat pelayanan di zona utara dengan fokus pengembangan sektor perdagangan (Revisi RTRW Kab.Subang Tahun 2002, hal. V.39 - V.43). Sebagaimana diketahui berdasarkan keragaman karakteristik fisiknya Kabupaten Subang terbagi menjadi 3 zona pelayanan yaitu zona selatan dengan pusat di Kecamatan Jalancagak, zona tengah berpusat di Kecamatan Pabuaran, pusat pengembangan utama di Kecamatan Subang, dan zona utara berpusat di Kecamatan Pamanukan.

Potensi utama di Kecamatan Pamanukan yang didukung dengan kebijakan pengembangan wilayah Kabupaten Subang dan Propinsi Jawa Barat adalah sektor pertanian. Hal ini tampak dari besarnya kontribusi sektor pertanian terhadap PDRB atas dasar harga konstan kecamatan, luas area pertanian, dan mata pencaharian penduduk.

\footnotetext{
*) Dosen Perencanaan Wilayah dan Kota Universitas PGRI Adi Buana Surabaya
} 
Kontribusi sektor pertanian terhadap PDRB

Kecamatan Pamanukan Tahun 2002 merupakan terbesar kedua setelah sektor perdagangan, hotel, dan restoran (sebesar $34,17 \%$ dari total PDRB kecamatan atau sebesar Rp. 39.165.000.000), yaitu sebesar $30,58 \%$ dari total PDRB kecamatan (Rp. 35.053.000.000). Luas lahan yang diperuntukkan bagi sektor pertanian di Kecamatan Pamanukan tahun 2006 mencapai lebih dari $60 \%$ dari seluruh luas wilayah kecamatan. Namun produksi padi mengalami penurunan sebesar $42,57 \%$, yaitu dari 95.000 tahun pada tahun 1993 menjadi 54.561 ton pada tahun 2003. Jumlah penduduk yang bermatapencaharian utama sebagai petani (baik sebagai petani pemilik maupun buruh tani) pada tahun 2006 sebesar 12.108 jiwa (50,18\% dari total pekerja di Kecamatan Pamanukan).

Kebijakan-kebijakan tersebut diatas mendorong perkembangan wilayah Kecamatan Pamanukan yang berakibat pada peningkatan jumlah penduduk dari 80.898 jiwa pada tahun 1996 menjadi 90.142 jiwa pada tahun 2007 (tingkat pertumbuhan rata-rata 1\% per tahun), dengan kepadatan penduduk ratarata pada tahun 2007 sebesar 118 jiwa/Ha. Jumlah penduduk di Kecamatan Pamanukan selain dipengaruhi oleh pertumbuhan alamiah (kelahiran) juga migrasi. Migrasi datang tahun 1998 sebesar 163 jiwa menurun menjadi 80 jiwa pada tahun 2007, sedangkan penduduk yang pindah ke luar wilayah Kecamatan Pamanukan tahun 1998 sebesar 113 jiwa menjadi 117 jiwa pada tahun 2007.

Jadi alasan perlunya pengendalian konversi lahan pertanian ke non pertanian di wilayah Kecamatan Pamanukan, adalah karena konversi lahan yang telah terjadi dan nampaknya cenderung terus terjadi merupakan ancaman terhadap keberlangsungan kegiatan pertanian lahan basah atau sawah yang merupakan salah satu fungsi utama yang diemban wilayah Kecamatan Pamanukan (secara makro spasial wilayah Kecamatan Pamanukan), serta merupakan sektor penghidupan utama bagi sebagian besar masyarakatnya sehingga diperlukan untuk menjaga keberlangsungan kehidupan rumah tangga pertanian yang menggantungkan hidupnya dari lahan pertanian, serta menjaga keberlangsungan kegiatan pertanian bagi rumah tangga pertanian tersebut (secara mikro).

\section{TINJAUAN TEORITIK}

Menurut Barlowe (1986),faktor-faktor yang mempengaruhi penggunaan lahan adalah faktor fisik dan biologis, faktor pertimbangan ekonomi dan faktor institusi (kelembagaan). Faktor fisik dan biologis mencakup kesesuaian dari sifat fisik seperti keadaan geologi, tanah, air, iklim, tumbuhtumbuhan, hewan dan kependudukan. Faktor pertimbangan ekonomi dicirikan oleh keuntungan, keadaan pasar dan transportasi. Faktor institusi dicirikan oleh hukum pertanahan, keadaan politik, keadaan sosial dan secara administrasi dapat dilaksanakan.

Menurut Panuju (1994), terjadinya pergeseran penggunaan lahan di suatu wilayah disebabkan oleh terjadinya konversi struktural di wilayah tersebut. Peningkatan jumlah dan kepadatan penduduk yang merupakan ciri dari konversi struktural menyebabkan meningkatnya kebutuhan lahan untuk mendukung pengembanga. Makin tinggi kebutuhan lahan untk permukiman, sarana pelayanan serta industri akan menurunkan struktur penggunaan lahan yang lain pada batasan tertentu.

Menurut Saefulhakim dan Nasution (1996), penggunaan lahan untuk aktifitas yang memiliki tingkat efisiensi lebih rendah, yang digunakan oleh aktifitas penggunaan lahan yang mampu memberikan tingkat efisiensi lebih tinggi. Hal ini berkaitan dengan teori sewa ekonomi lahan (land rent) yang dikemukan oleh Barlowe (1986), bahwa setiap jenis penggunaan lahan pertanian maupun non pertanian memiliki nilai sewa ekonomi lahan yang berbeda. Bila mekanisme pasar terus berlangsung, maka penggunaan lahan yang mempunyai nilai land rent yang lebih besar relatif lebih mudah menekan dan menggantikan posisi penggunaan lahan yang land rent kecil.

Menurut Mc Neil (1998) faktor-faktor yang mendorong perubahan penggunaan lahan adalah politik, ekonomi, demografi dan budaya. Aspek politik adalah adanya kebijakan yang dilakukan oleh pengambil keputusan mempengaruhi perubahan penggunaan lahan. Pertumbuhan ekonomi, perubahan pendapatan dan konsumsi juga merupakan faktor penyebab perubahan penggunaan lahan. Sebagai contoh, meningkatnya kebutuhan akan ruang tempat hidup, transportasi dan tempat rekreasi mendorong terjadinya perubahan penggunaan lahan. Perubahan penggunaan lahan di suatu wilayah merupakan pencerminan upaya manusia memanfaatkan dan mengelola sumberdaya lahan akan berpengaruh terhadap manusia dan kondisi lingkungannya.

Sedangkan pendapat ahli lain, faktor yang mempengaruhi proses perubahan penggunaan lahan yaitu faktor yang berasal dari luar pertanian dapat berupa pertanian 
dapat berupa faktor kebijakan dan non kebijakan (Nasution dan Winoto, 1995). Secara empiris telah dibutikan pada wilayah yang akan dikembangkan sebagai kawasan industri laju perubahan lahan relatif cepat daripada daerah lainnya (Sumaryanto, 1995). Demikian pula strategi pembangunan wilayah yang bias terhadap pembangunan perkotaan dan wisata dengan basis sektor industri dan jasa akan menarik penggunaan lahan pertanian ke non pertanian. Faktor non kebijakan yang dapat mempercepat proses perubahan penggunaan lahan antara lain struktur perkenomian wilayah dan proses perpindahan penduduk dari desa ke kota. Pergeseran peran dan kontribusi sektor pertanian dalam perekonomian wilayah akan berpengaruh terhadap proses perubahan fungsi lahan pertanian (Hermanto, 1996). Faktor dari sektor petanian yang mempengaruhi proses perubahan penggunaan lahan antara lain rendahnya rasio sewa ekonomi lahan pertanian terhadap sewa ekonomi lahan untuk sektor non pertanian, kondisi kepemilikan lahan pertanian yang sempit dan terpencar, sehingga kurang memberikan insentif yang memadai untuk mempertahankan usaha tanianya (Irawan, 1997).

Alih fungsi lahan dapat terjadi disebabkan oleh dua faktor, yaitu faktor eksternal (meliputi tingkat urbanisasi dan kondisi sosial ekonomi di suatu wilayah), serta faktor internal (meliputi lokasi lahan, guna lahan, ukuran lahan, pendapatan rumah tangga, aspek kebijaksanaan yang berlaku, serta aktor-aktor yang terlibat dalam proses alih fungsi lahan pertanian) (Fadjarajani,
2001:36). Pembagian faktor internal dan eksternal juga dilakukan oleh Kustiwan (1996) yang menyatakan bahwa alih fungsi lahan pertanian dipengaruhi oleh faktor eksternal (meliputi perkembangan kawasan terbangun, pertumbuhan penduduk perkotaan, serta pertumbuhan dan pergeseran struktur ekonomi) dan faktor internal (meliputi pertumbuhan rumah tangga pertanian pengguna lahan dan perubahan luas penguasaan lahan oleh rumah tangga pertanian pengguna lahan).

Menurut Pierce (1981 dalam Firman, 1997) faktor yang mempengaruhi alih fungsi lahan yaitu: (1) perubahan penduduk, (2) fungsi ekonomi yang dominan, (3) ukuran kota, (4) rata-rata nilai lahan permukiman, (5) kepadatan penduduk, (6) wilayah geografi, dan (7) lahan pertanian potensial.

Secara umum, konversi lahan pertanian mempunyai konsekuensi (Firman, 1997), yaitu:

1. Dampak langsung terhadap hilangnya lahan pertanian yang mempengaruhi produksi pertanian, dimana dampak ini akan menghilangkan pekerjaan di bidang pertanian bagi petani pemilik maupun penggarap, menghilangkan investasi pada infrastruktur pertanian, serta berdampak negatif terhadap lingkungan seperti kerusakan lingkungan.

2. Dampak tidak langsung pada penduduk yang datang dari pusat kota ke pinggiran kota, dimana dampak ini akan meningkatkan pembangunan perumahan dan kesempatan pekerjaan, serta akan merubah struktur sosial ekonomi di pinggiran kota.

Tabel 1. Perbandingan Kasus-kasus Dampak Sosial Ekonomi dari Konversi Lahan Pertanian

\begin{tabular}{|c|c|c|c|c|}
\hline $\begin{array}{c}\text { Wilayah Jalur } \\
\text { Bandung-Soreang }\end{array}$ & $\begin{array}{l}\text { Kec. Rancaekek } \\
\text { Kab. Bandung }\end{array}$ & $\begin{array}{l}\text { Kec. Lembang Kab. } \\
\text { Bandung }\end{array}$ & $\begin{array}{l}\text { Wilayah Pantura } \\
\text { Pulau Jawa }\end{array}$ & $\begin{array}{c}\text { Koridor Bandung- } \\
\text { Soreang }\end{array}$ \\
\hline $\begin{array}{l}\text { Pemilik lahan dan } \\
\text { yang menjual } \\
\text { lahan diuntungkan } \\
\text { dengan adanya } \\
\text { konversi lahan }\end{array}$ & $\begin{array}{l}\text { Pemilik lahan dan } \\
\text { yang menjual lahan } \\
\text { diuntungkan dengan } \\
\text { adanya konversi } \\
\text { lahan }\end{array}$ & $\begin{array}{l}\text { Terdapat } \\
\text { kecenderungan } \\
\text { kepemilikan lahan } \\
\text { pertanian semakin } \\
\text { menyempit. Faktor ini } \\
\text { mempengaruhi tingkat } \\
\text { pendapatan petani }\end{array}$ & $\begin{array}{l}\text { Fragmentasi } \\
\text { kepemilikan lahan } \\
\text { pertanian } \\
\text { berkaitan erat } \\
\text { dengan laju alih } \\
\text { fungsi lahan }\end{array}$ & $\begin{array}{l}\text { Pemilik lahan dan } \\
\text { yang menjual lahan } \\
\text { diuntungkan } \\
\text { dengan adanya } \\
\text { konversi lahan }\end{array}$ \\
\hline $\begin{array}{l}\text { Buruh dan petani } \\
\text { penyakap hanya } \\
\text { terserap } 20 \% \text { di } \\
\text { lapangan kerja } \\
\text { baru, sisanya } \\
\text { urbanisasi dan } \\
\text { transmigrasi }\end{array}$ & $\begin{array}{l}\text { Terdapat pergeseran } \\
\text { struktur mata } \\
\text { pencaharian } \\
\text { penduduk } \\
\text { (khususnya petani } \\
\text { penyakap \& buruh } \\
\text { tani), dari pertanian } \\
\text { menjadi non } \\
\text { pertanian (industri, } \\
\text { perdagangan \& jasa) }\end{array}$ & $\begin{array}{l}\text { Status pekerjaan pokok } \\
\text { dan sampingan } \\
\text { berhubungan erat } \\
\text { dengan perubahan } \\
\text { kondisi sosial ekonomi } \\
\text { rumah tangga petani } \\
\text { Tingkat pendidikan, } \\
\text { jumlah tanggungan } \\
\text { keluarga, \& penggunaan } \\
\text { hasil penjualan lahan } \\
\text { pertanian berhubungan } \\
\text { erat dengan perubahan } \\
\text { kondisi sosial ekonomi } \\
\text { rumah tangga petani }\end{array}$ & $\begin{array}{l}\text { Laju alih fungsi } \\
\text { lahan pertanian } \\
\text { sangat ditentukan } \\
\text { oleh tingkat } \\
\text { urbansasi dan } \\
\text { konversi ekonomi } \\
\text { wilayah }\end{array}$ & $\begin{array}{l}\text { Petani bukan } \\
\text { pemilik lahan } \\
\text { beralih pekerjaan } \\
\text { ke pekerjaan non } \\
\text { pertanian sebagai } \\
\text { buruh industri, } \\
\text { buruh bangunan } \\
\text { atau tukang becak }\end{array}$ \\
\hline
\end{tabular}




\section{METODE PENELITIAN Wilayah Studi}

Wilayah studi adalah desa-desa wilayah Kecamatan Pamanukan yang berada di sepanjang Jalur Pantura.

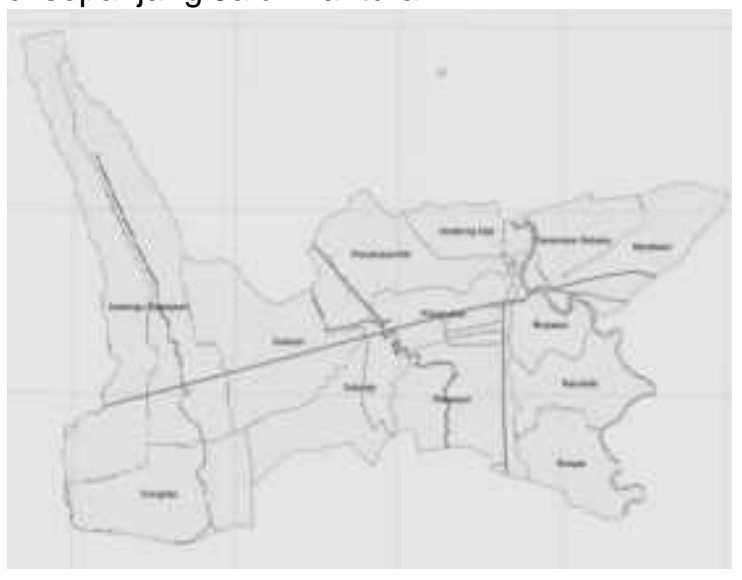

Gambar 1. Wilayah Studi

\section{Pemilihan Sampel}

Untuk mendapatkan gambaran kondisi sosial ekonomi petani secara aktual berdasarkan pengamatan langsung, maka diperlukan informasi yang diperoleh dari rumah tangga petani dan rumah tangga pendatang.

Sampel rumah tangga petani

Didapatkan 95 sampel rumah tangga petani tersebar di seluruh wilayah studi dengan proporsi sesuai dengan jumlah populasi KK petani.

Sampel rumah tangga pendatang

Didapatkan 42 sampel rumah tangga pendatang tersebar di seluruh wilayah studi dengan proporsi sesuai dengan jumlah penduduk pendatang.

\section{Metode Analisis Data}

Metode analisis yang digunakan dalam penelitian ini adalah analisis deskriptif dengan bantuan program aplikasi komputer SPSS.

\section{PEMBAHASAN}

\section{Dampak Konversi Lahan Pertanian Terhadap Konsisi Sosial Ekonomi Petani : Skala Makro Kecamatan Pamanukan}

\section{Perubahan Penggunaan Lahan}

Berdasarkan data-data sekunder dan hasil overlay peta penggunaan lahan, maka dapat diketahui total luas lahan pertanian yang terkonversi menjadi lahan terbangun sebesar $1.675 \mathrm{Ha}$ atau $21,64 \%$ dari luas total wilayah Kecamatan Pamanukan. Selain itu di Kecamatan Pamanukan juga terjadi konversi hutan bakau menjadi bangunan dan tambak yaitu sebesar $66 \mathrm{Ha}$ atau 0,85\% dari luas total wilayah kecamatan. Dengan demikian dapat disimpulkan bahwa, luas lahan pertanian di Kecamatan Pamanukan menurun sementara luas lahan terbangun semakin meningkat. Kondisi ini bertentangan dengan kebijakan pemerintah Propinsi Jawa Barat yang menetapkan Kecamatan Pamanukan sebagai salah satu lumbung padi Jawa Barat.

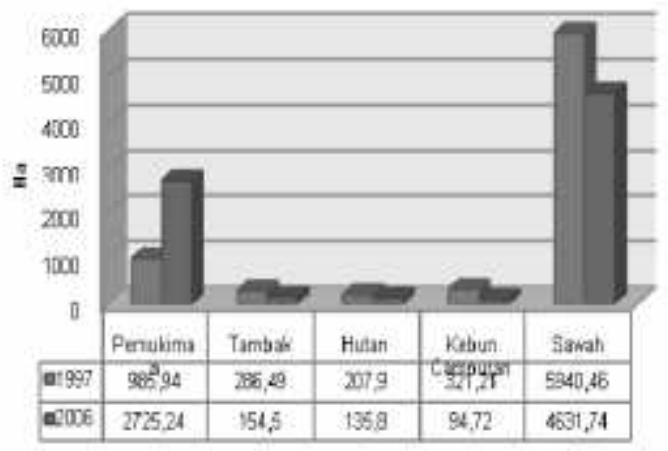

\section{Gambar 2. Perubahan Penggunaan Lahan Kecamatan Pamanukan 1997 - 2006}

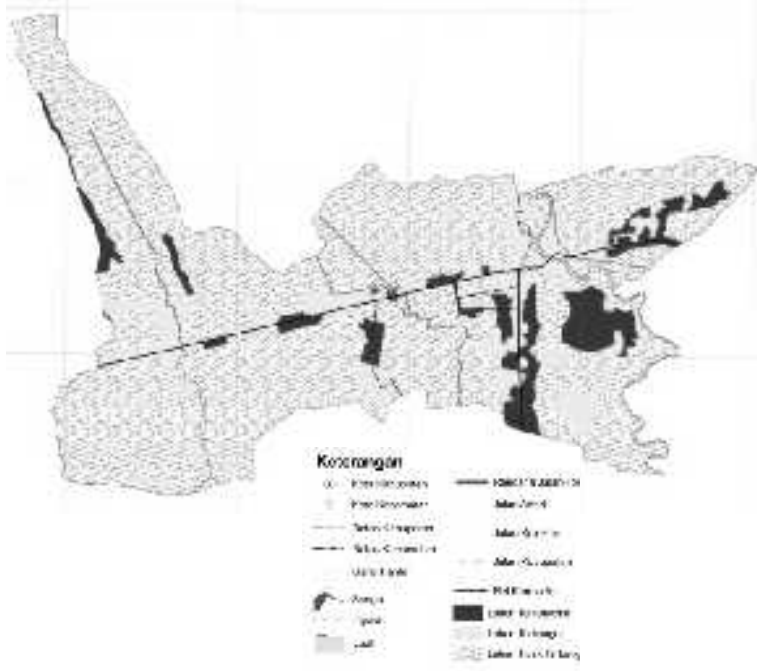

Gambar 3. Konversi Lahan Kecamatan Pamanukan Tahun 1997-2006

Perubahan paling signifikan terjadi pada guna lahan sawah. Luas sawah pada tahun 1997 adalah 2.894,18 $\mathrm{Ha}$ atau sebesar $72,42 \%$ dari total luas wilayah studi. Pada tahun 2006, sawah telah dialihfungsikan sebesar $1.378 \mathrm{Ha}$ atau sebesar $34,48 \%$ dari total luas sawah pada tahun 1997. Peningkatan kawasan terbangun tertinggi terdapat di Desa Mulyasari dimana jumlah luas penggunaan pada tahun 2006 adalah delapan belas kali lipat luasan pada tahun 1997. Hal yang mendorong perubahan ini adalah terkait peran Desa Mulyasari sebagai ibu kota Kecamatan Pamanukan dengan fungsi sebagai pusat kegiatan perdagangan dan permukiman. 


Jenis penggunaan lahan yang
mengalami penyusutan luas cukup tinggi adalah tambak. Penyusutan terjadi hampir di Desa Batangsari dan Sukamaju. Penyusutan luas tambak terbesar terjadi di Desa Sukamaju dimana sebanyak $100 \%$ total luas tambak pada tahun 1997 telah dialih fungsikan, sebagian besar menjadi sawah tadah hujan.

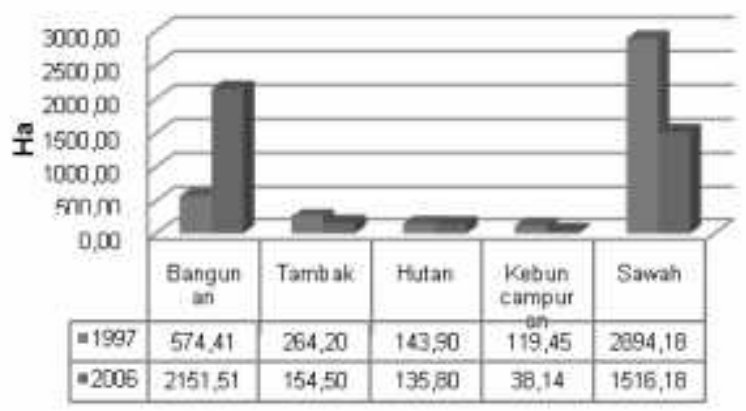

\section{Gambar 4. Perubahan Penggunaan Lahan Wilayah Studi Tahun 1997 dan 2006}

Faktor Pengaruh: Kebijakan Pengembangan Kecamatan Pamanukan

Kebijakan pengembangan Kecamatan

Pamanukan yang secara tidak langsung mempengaruhi perubahan guna lahan antara lain:

1. Berdasarkan Revisi RTRW Kabupaten Subang Tahun 2002, wilayah studi termasuk dalam kelompok wilayah pengembangan II (Kecamatan Pamanukan dan sekitarnya). dimana peran dan fungsinya adalah sebagai pusat pertumbuhan dan pusat pelayanan WP II, pusat koleksi dan distribusi hasil pertanian, perikanan dan kebutuhan pokok. Penetapan fungsi ini dapat menimbulkan pengaruh yang kuat bagi perkembangan wilayah sekitarnya, terutama pertumbuhan kegiatan pada sektor yang menunjang kegiatan pertanian dan perdagangan. Wilayah-wilayah yang distimulator perkembangan wilayahnya oleh Kecamatan Pamanukan, yaitu Kecamatan Ciasem, Legonkulon, Blanakan, Pusakanagara, Binong, dan Compreng.

2. Perubahan lahan pertanian ke non pertanian diperbolehkan dengan mengkonversi sawah tadah hujan yang dinilai kurang produktif.

3. Pengembangan sawah irigasi teknis difokuskan di wilayah utara Kabupaten Subang guna mendukung ketahanan pangan nasional. Begitu pula untuk perikanan tambak dan laut.
4. Pengarahan dan pembatasan kegiatan permukiman perkotaan terutama di sepanjang jalan nasional (jalur pantura) dalam kaitan dengan pengendalian pemanfaatan sawah irigasi teknis.

5. Penyediaan sarana perkotaan sesuai dengan fungsi kota dengan pendekatan Program Pembangunan Prasarana Kota Terpadu (P3KT), yang mencakup penyediaan air bersih, jalan kota, sistem jaringan drainase, sistem jaringan air kotor, persampahan serta perbaikan kampung.

6. Pengembangan kegiatan ekonomi kota (jasa dan perdagangan) dalam rangka memacu pertumbuhan dan perkembangan daerah serta memperluas kesempatan kerja

Dengan meningkatnya konversi lahan pertanian ke penggunaan non pertanian di Kecamatan Pamanukan menyebabkan adanya pergeseran struktur mata pencaharian penduduk dari sektor pertanian ke sektor perdagangan dan jasa. Namun karena tingkat pendidikan penduduk wilayah Kecamatan Pamanukan yang relatif rendah (tamatan SD dan SLTP/sederajat sebesar $46,73 \%$ dari total jumlah penduduk tahun 2006), mereka tidak dapat terserap di sektor perdagangan dan jasa karena tidak masuk dalam kualifikasi penerimaan tenaga kerja sektor perdagangan dan jasa (umumnya minimal tamatan SLTA/sederajat.

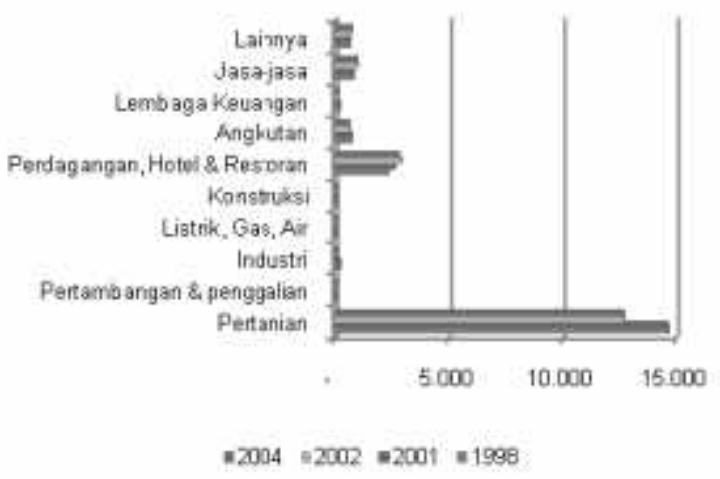

Gambar 5. Perubahan Struktur Mata Pencaharian Penduduk Kecamatan Pamanukan

Selain itu juga menyebabkan perubahan kepemilikan lahan pertanian kurang dari 0,1 Ha berkurang sebesar 47,49\% per tahun, $0,1-0,5 \mathrm{Ha}$ berkurang sebesar $17,92 \%$ per tahun, $0,6-1 \mathrm{Ha}$ berkurang sebesar $18,76 \%$ per tahun, dan kepemilikan lahan dengan luasan lebih dari $1 \mathrm{Ha}$ berkurang sebesar $57,74 \%$ per tahun. Dengan demikian dapat disimpulkan, selama periode 2000-2006 terjadi perubahan struktur 
kepemilikan lahan pertanian dan yang paling menonjol adalah makin banyaknya petani gurem dengan luas penguasaannya semakin sempit atau bahkan tidak punya lahan, dan di pihak lain terjadi pengumpulan penguasaan lahan pertanian pada sebagian rumah tangga petani.

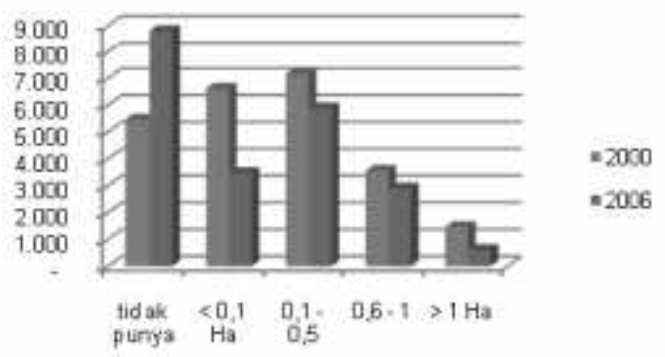

Gambar 6. Perubahan Kepemilikan Lahan Pertanian Kecamatan

Seiring dengan semakin berkembangnya kegiatan perekonomian wilayah (khususnya sektor perdagangan dan jasa) membuat Kecamatan Pamanukan menjadi daerah tujuan migrasi baik dari daerah urban (seperti Jakarta, Bekasi) maupun daerah rural (Majalengka, Pusakanagara).

Net migrasi di Kecamatan Pamanukan tahun 2007 adalah sebesar - 37, yang berarti bahwa migrasi keluar lebih besar dibandingkan dengan migrasi masuk. Ratarata pertumbuhan migrasi datang ke Kecamatan Pamanukan terbesar adalah Desa Mulyasari sebesar $895,05 \%$ per tahun, sedangkan migrasi keluar terbesar adalah Desa Batangsari sebesar $178,57 \%$ per tahun. Berdasarkan data sekunder tersebut menunjukkan bahwa Desa Mulyasari yang juga merupakan wilayah pusat kota Kecamatan Pamanukan merupakan salah satu daerah tujuan migrasi. Hal ini sesuai dengan konversi lahan pertanian menjadi lahan terbangun di Desa Mulyasari juga terbesar sekitar 18 kali penggunaan lahan sawah tahun 1997.

Migrasi yang keluar umumnya dengan daerah tujuan Jakarta, Bandung, luar negeri (Arab Saudi, Korea, Malaysia, Singapura, Taiwan, Hongkong, Jepang, dII). Penduduk mulai marak menjadi TKW di mulai tahun 2000, dengan alasan kepindahan adalah ekonomi rumah tangga. Perjalanan penduduk ke luar daerah atau luar negeri secara tidak langsung disebabkan oleh persaingan penduduk asli dan pendatang dalam mencari peluang kerja sektor non pertanian yang mulai meggantikan dominasi penyerapan tenaga kerja sektor pertanian. Perkembangan sarana perdagangan dan jasa di Kecamatan Pamanukan sesuai dengan laju konversi lahan pertanian menjadi bangunan pada tahun 1997-2006 yaitu sebesar 34,48\% per tahun.

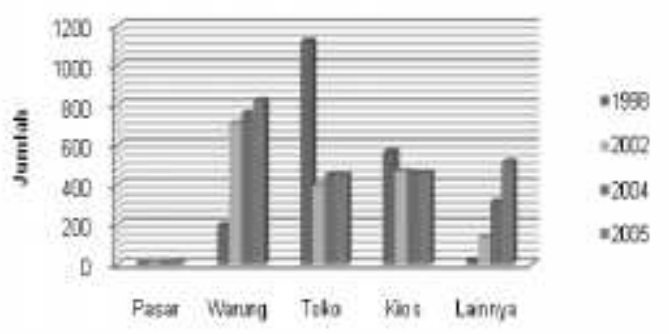

Gambar 7. Perubahan Jumlah Sarana Ekonomi Kecamatan Pamanukan

Dampak Konversi Lahan Pertanian Terhadap Konsisi Sosial Ekonomi Petani : Skala Makro (Rumah Tangga Petani)

\section{Perubahan Jenis Mata Pencaharian}

Perubahan jenis mata pencaharian utama rumah tangga responden di wilayah studi dalam 10 tahun terakhir (1997-2007).

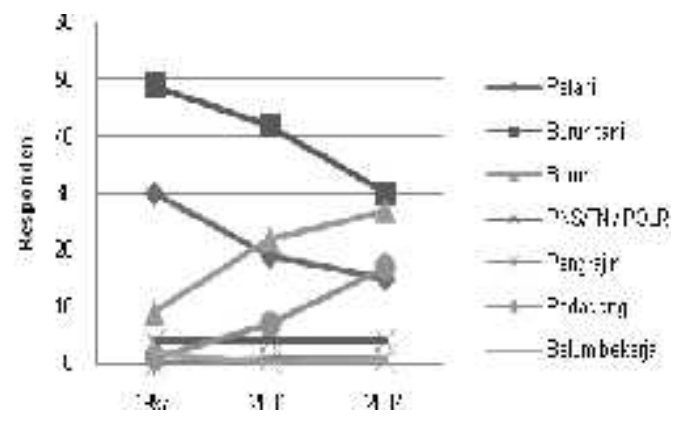

Gambar 8. Perubahan Mata Pencaharian Utama Rumah Tangga Responden (1997-2007)

Sebagian lahan yang dulunya digunakan untuk kegiatan pertanian baik sawah maupun perkebunan, kini ada yang berubah menjadi area terbangun sebagai akibat dari perkembangan kegiatan perkotaan di Kecamatan Pamanukan. Ada pula lahan yang dulunya untuk pertanian kini berubah kepemilikan dan belum difungsikan oleh pemiliknya. Di lain hal terdapat pula lahan yang berubah kepemilikan dan tetap digunakan untuk kegiatan pertanian, namun akibat perubahan kepemilikan tersebut, responden yang dulunya petani kini hanya bekerja sebagai petani penggarap atau buruh tani, dengan keuntungan yang diperoleh relatif lebih kecil, sehingga mata pencaharian ini semakin lama semakin ditinggalkan oleh rumah tangga responden. Namun berdasarkan hasil wawancara dengan beberapa petani di wilayah studi, konversi 
lahan pertanian di sepanjang Jalur Pantura tersebut lebih menguntungkan bagi mereka, karena mereka menjual lahan pertanian di sepanjang Jalur Pantura dengan harga mahal (tahun 2007 sekitar 150 juta per $\mathrm{Ha}$ ) dan mereka belikan lahan pertanian di wilayah lain yang lebih jauh seperti Kecamatan Binong, Kecamatan Pusakanagara, Kecamatan Blanakan, dan lain-lain.

Berdasarkan hasil survei, diketahui bahwa prosentase rumah tangga responden yang memiliki mata pencaharian tambahan dari tahun 1997 sampai dengan 2007 semakin meningkat dari tahun ke tahun. Peningkatan ini sekaligus juga membuat prosentase rumah tangga responden yang tidak mempunyai mata pencaharian tambahan semakin menurun. Prosentase rumah tangga responden yang memiliki mata pencaharian tambahan dengan yang tidak memiliki pada tahun 2007, prosentase yang lebih besar adalah responden yang memiliki mata pencaharian tambahan (78,95\%).

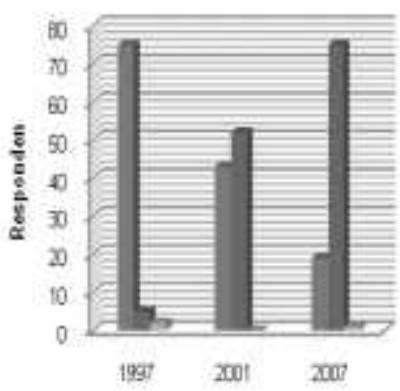

-Td ak maneilibmara peccharian tambitar -Momikinata petcatiariat tarbiatan

asium bekeifa

Gambar 9. Perbandingan Rumah Tangga Responden yang Memiliki dan Tidak Memiliki Mata Pencaharian Tambahan (1997-2007)

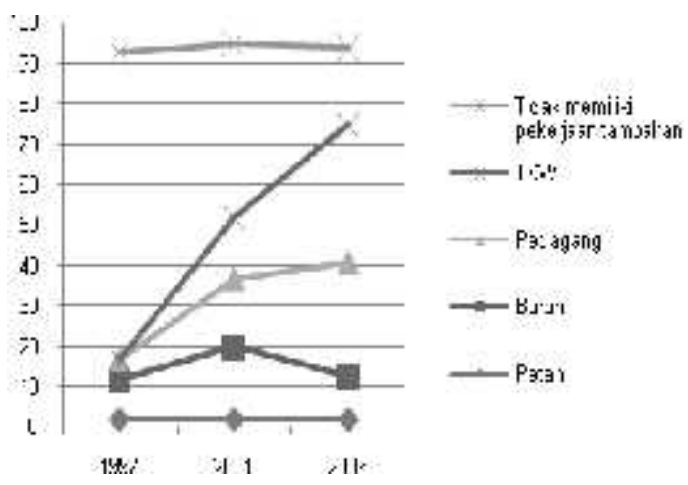

Gambar 10. Perubahan Mata Pencaharian Tambahan Rumah Tangga Responden (19972007)

Untuk mengetahui hubungan antara perubahan struktur mata pencaharian dengan konversi lahan pertanian, maka dipergunakan analisis regresi linear dengan $\alpha=0,05$ (Convidence Interval 95\%).
$\mathrm{Y}=0,571 \mathrm{X}+0,857$

dimana, $y=$ konversi lahan pertanian $(\mathrm{Ha})$

$\mathrm{X}=$ perubahan struktur mata

pencaharian (Rumah Tangga)

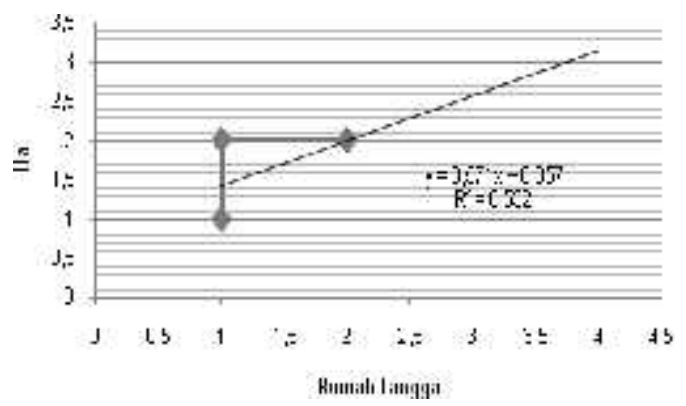

Gambar 11. Hubungan Konversi Lahan

Pertanian Vs Perubahan Struktur Mata Pencaharian

\section{Perubahan Kepemilikan Lahan Pertanian}

Kepemilikan lahan pertanian
responden luas $<0,5$ Ha sebesar $4 \%$, dan $0,5-$ $1 \mathrm{Ha}$ sebesar 3\%. Sedangkan untuk responden yang memiliki lahan pertanian $>1$ $\mathrm{Ha}(8,1 \%)$ cenderung bertahan. Hal ini bertentangan dengan standar kepemilikan lahan oleh rumah tangga petani, dimana menurut Sayogyo (dalam Suhendar, 1995:46) minimal sebesar 0,25-0,5 $\mathrm{Ha}$ dan menurut Edmuson (dalam Suhendar, 1995:46) sebesar $0,5 \mathrm{Ha}$. Jika dikaitkan dengan konversi lahan pertanian, maka dapat disimpulkan bahwa di wilayah studi telah terjadi alih fungsi lahan pertanian yang mengakibatkan sebagian besar petaninya tidak mempunyai lahan pertanian lagi. Perbandingan antara petani pemilik lahan pertanian dengan petani non pemilik pada tahun 1997 adalah 1: 2, sedangkan tahun 2007 adalah $1: 5$.

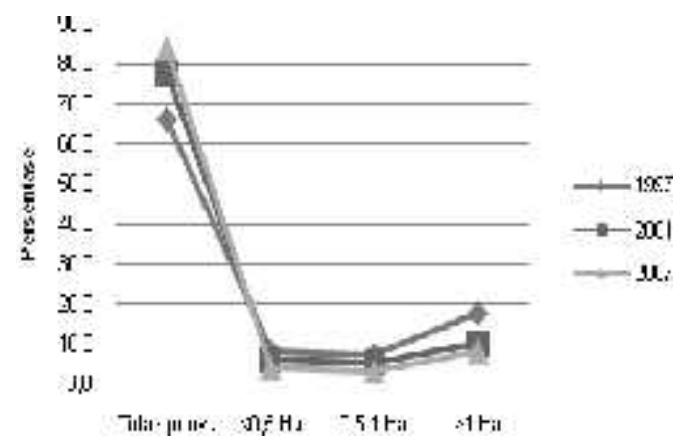

Gambar 12. Perubahan Luasan Kepemilikan Lahan Pertanian Responden (1997-2007)

Jumlah responden menurut lokasi lahan yang dimiliki petani di desa tempat tinggal $(3,0 \%)$, dan di desa wilayah Kec. 
Pamanukan sebesar (12,1\%). Sedangkan yang terbesar adalah responden yang tidak mempunyai lahan pertanian sebesar $84,8 \%$.

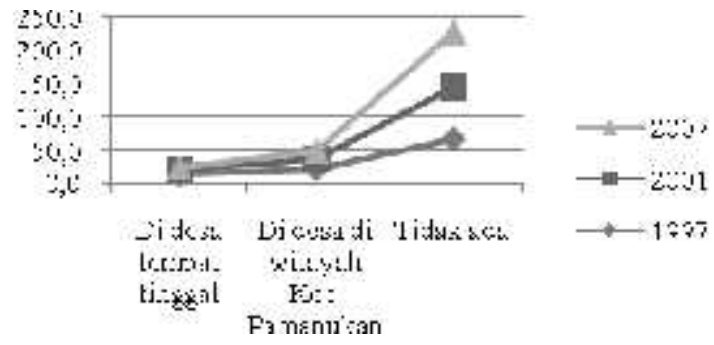

Gambar 13. Perubahan Lokasi Kepemilikan Lahan Pertanian Responden (1997-2007)

Jangka waktu kepemilikan lahan pertanian tahun 2007 sebagian besar berkisar antara $1-5$ tahun $(35,3 \%), 5-10$ tahun $(29,4 \%)$ dan warisan orang tua $(29,4 \%)$. Dengan demikian, responden mulai menganggap bahwa lahan pertanian adalah asset investasi bukan lagi faktor produksi yang bermakna ekonomis dalam arti sebagai sumber kehidupan sehingga semakin memacu konversi lahan. Keadaan ini akan menghilangkan pekerjaan bagi penduduk di wilayah studi yang bermatapencaharian di sektor pertanian.

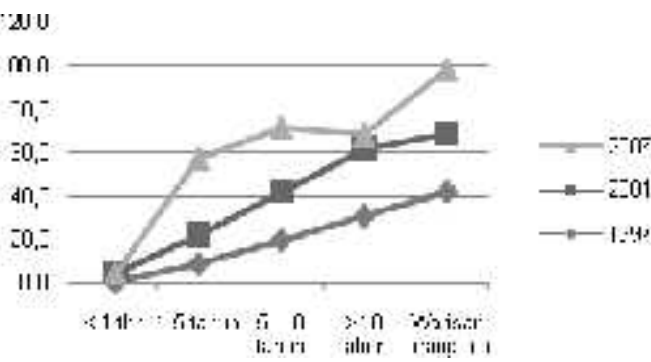

Gambar 14. Perubahan Jangka Waktu Kepemilikan Lahan Pertanian Responden (1997-2007)

Penjualan lahan pertanian di wilayah studi dapat mengakibatkan beralih fungsinya lahan tersebut menjadi kegiatan non pertanian yang telah berlangsung sejak tahun 1990-an. Umumnya petani menjual lahan pertanian dengan luas kurang dari $0,5 \mathrm{Ha}$ dan hanya sebagian kecil yang menjual lahan pertaniannya dengan luas diatas $1 \mathrm{Ha}$. Luas lahan pertanian yang dijual ini berkaitan dengan luas kepemilikan lahan pertanian, dimana luas kepemilikan lahan pertanian sempit $(<1 \mathrm{Ha})$ dan luas lahan pertanian yang dijualpun rata-rata sempit juga $(<0,5$
$\mathrm{Ha)}$

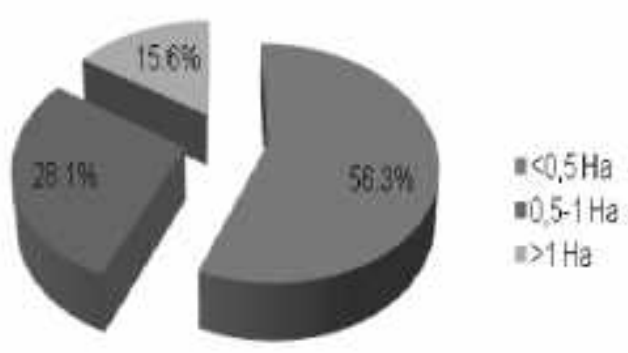

\section{Gambar 15. Luas Lahan Milik Responden Yang Terkonversi (1997-2007)}

Alasan responden menjual lahan pertanian yang berada di sepanjang Jalur Pantura karena harga jual tanah pertanian tinggi $(67,5 \%)$, membiayai pendidikan anak $(10 \%)$, mencukupi kebutuhan hidup $(7,5 \%)$, membangun rumah $(5 \%)$, bagi waris $(5 \%)$, modal usaha $(2,5 \%)$ dan ibadah haji $(2,5 \%)$. Tingginya harga jual lahan pertanian berkaitan dengan lokasi strategis dan ketersediaan sarana prasarana di wilayah studi. Kondisi ini mendorong banyak pendatang atau investor dari luar memilih wilayah studi sebagai tempat membuka usaha baru atau berinvestasi di bidang jasa (seperti hotel, restoran, SPBU, perumahan, dan lain sebagainya).
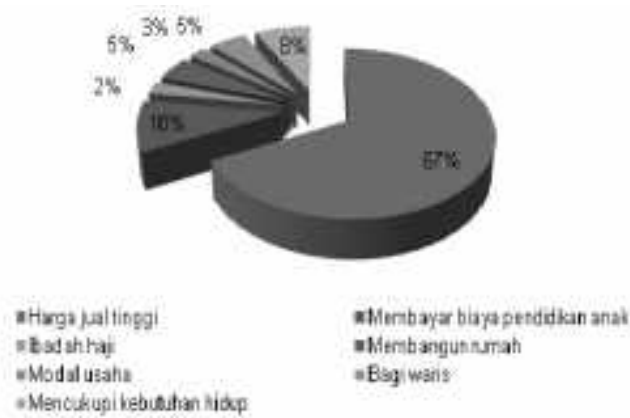

Gambar 16. Proporsi Alasan Petani Melakukan Konversi Lahan Pertanian

Penggunaan uang yang diperoleh petani sebagai hasil penjualan lahan pertaniannya secara umum digunakan untuk membeli lahan pertanian di lokasi yang lebih jauh dengan harga lebih murah, membangun rumah, dan keperluan sehari-hari. 


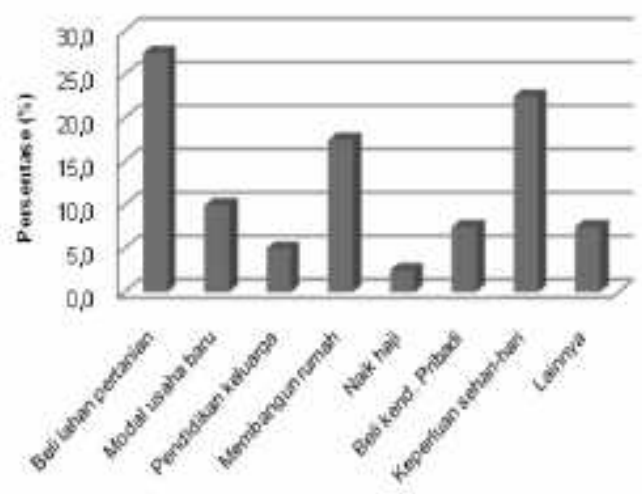

Gambar 17.Pemanfaatan Uang Hasil Penjualan Lahan Pertanian

Hasil survei primer rumah tangga petani, menunjukkan $62,5 \%$ penjualan lahan pertanian yang dilakukan petani mengakibatkan konversi lahan pertanian di wilayah tersebut. Hal ini berarti bahwa $37,5 \%$ lahan pertanian mempunyai peluang untuk terkonversi menjadi lahan terbangun jika tidak segera diantisipasi oleh pemerintah daerah.

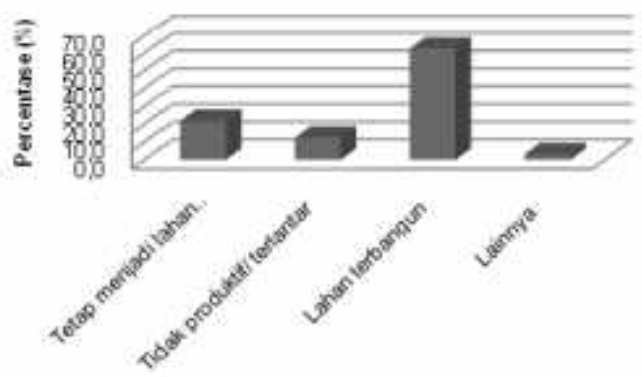

Gambar 18. Pemanfaatan Lahan Pertanian Yang Telah Dijual

Hubungan antara perubahan kepemilikan lahan pertanian dengan konversi lahan pertanian, maka dipergunakan analisis regresi linear dengan $\alpha=0,05$ (Convidence Interval 95\%).

$$
Y=0,238 X+1,290
$$

dimana, $y=$ konversi lahan pertanian $\mathrm{x}=$ perubahan kepemilikan lahan pertanian

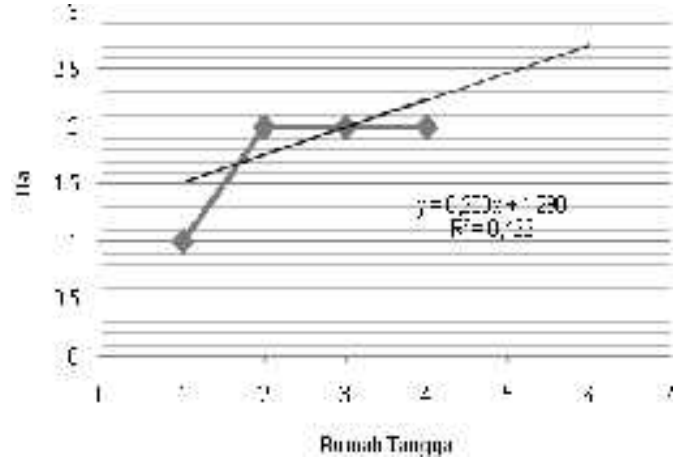

Gambar 19. Hubungan Konversi Lahan Pertanian Vs Perubahan Kepemilikan Lahan Pertanian

\section{Migrasi}

Peningkatan jumlah migrasi ke wilayah studi, sesuai dengan konversi lahan pertanian di wilayah studi sebesar 39,47\% menjadi kawasan terbangun. Selain itu tampaknya tidak terlepas dari perkembangan sarana prasarana perkotaan di Kecamatan Pamanukan, seperti akses yang semakin membaik, kelengkapan sarana prasarana yang mendukung fungsi Kecamatan Pamanukan sebagai pusat pelayanan zona utara dalam pengembangan wilayah Kabupaten Subang, dan sebagainya.

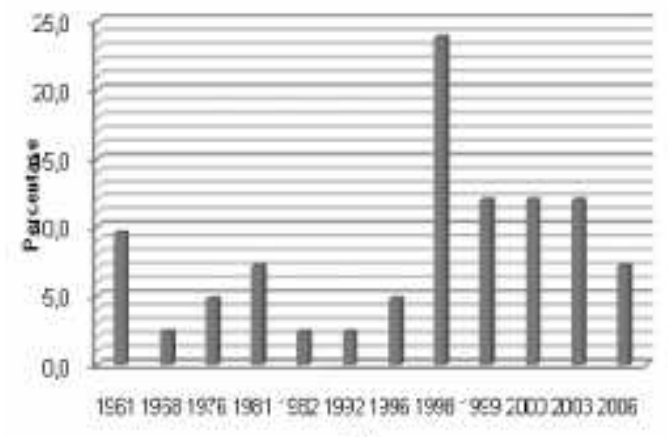

Taluin

Gambar 20. Tahun Pertama Tinggal Responden Pendatang Di Wilayah studi

Alasan yang melatarbelakangi responden pendatang dalam melakukan perpindahan ke wilayah sepanjang Jalur Pantura Kecamatan Pamanukan. Alasanalasan tersebut adalah: diharuskan pindah oleh karena pekerjaan, mencari pekerjaan, memulai usaha/pekerjaan baru, dekat dengan lokasi tempat kerja, pendapatan yang lebih baik, perubahan status perkawinan, ikut suami/isteri/orang tua/anak, ikut saudara kandung/famili lain, prasarana dan sarana yang lengkap, kemudahan akses, dekat dengan Kota Pamanukan, harga yang terjangkau, faktor keamanan, dan sebaganya. 


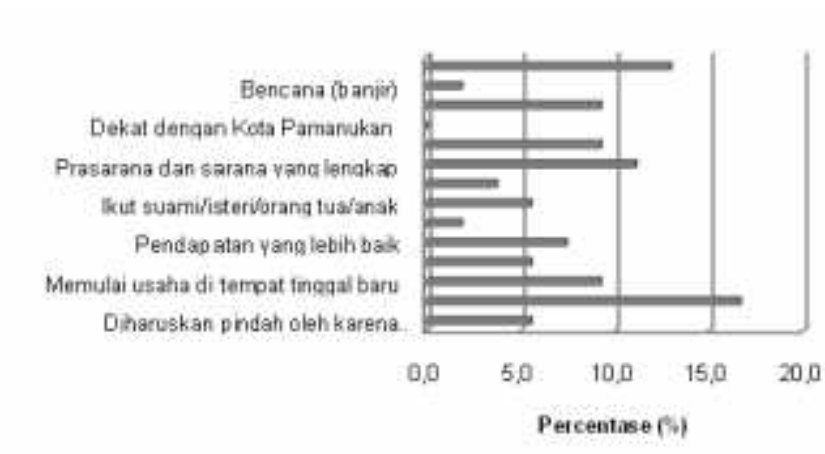

Gambar 21. Alasan Dilakukannya Perpindahan oleh Responden Pendatang ke Wilayah studi

Berdasarkan hasil wawancara dengan Kaur Ekonomi Kecamatan Pamanukan (Bpk. A. Suparman), "migrasi yang dilakukan oleh penduduk wilayah studi adalah migrasi keluar ketika musim paceklik, dengan menjadi buruh bangunan di Jakarta dan Bekasi.., hal ini disebabkan karena jumlah pemilik lahan pertanian lebih kecil dibandingkan jumlah buruh tani sehingga tenaga kerja buruh tani berlebih.". Hal ini juga didukung oleh kajian yang dilakukan oleh Sumaryanto dan Sudaryanto (1989) di Propinsi Jawa Tengah bahwa pola migran ternyata dipengaruhi oleh permintaan tenaga kerja di dalam desa. Pada saat permintaan tenaga kerja di dalam desa cukup tinggi seperti pada saat tanam dan panen maka arus migrasi ke luar desa lebih kecil dibandingkan masa lainnya.

Selain itu migrasi juga didorong oleh tingkat umur dan pendidikan seseorang, serta rendahnya rasio kepemilikan luas lahan (Pasaribu, 2000:244). Berdasarkan pernyataan tersebut maka dapat disimpulkan bahwa migrasi keluar baik secara komutasi maupun tetap di wilayah studi cukup besar, hal ini disebabkan karena jumlah penduduk usia 15 -50 tahun di wilayah studi cukup besar (62,47\% dari total jumlah penduduk), tingkat pendidikan rendah (tamatan SD/SLTP dan sederajat sebesar $46,73 \%$ ), dan jumlah petani non pemilik lebih besar daripada jumlah petani pemilik tahun 2007 dengan perbandingan 5 : 1. Selain itu adanya kecenderungan petani pemilik memilih untuk mengerjakan sendiri lahannya daripada disewakan atau disakapkan kepada buruh tani (berdasarkan hasil wawancara dengan beberapa petani pemilik lahan pertanian di wilayah studi).

Hasil survei rumah tangga, diperoleh bahwa 34 orang yang mempunyai pekerjaan tambahan sebagai TKW baik di Arab Saudi, Korea, Jepang, Malaysia, Singapura, dan lainlain. Sedangkan jumlah responden yang menjadi buruh bangunan di Jakarta atau Bekasi ketika musim paceklik sebesar 7 orang. Alasan mencari pekerjaan keluar daerah mayoritas adalah masalah ekonomi rumah tangga.

\section{KESIMPULAN}

Trend perubahan penggunaan lahan di Kecamatan Pamanukan dari tahun 1997 2006 adalah berkurangnya lahan sawah sebesar $17,07 \%$, kebun campuran sebesar $2,92 \%$, tambak sebesar $1,64 \%$, dan hutan bakau sebesar $0,85 \%$. Sedangkan trend perubahan penggunaan lahan di wilayah studi dari tahun 1997 ke tahun 2006 adalah berkurangnya kawasan sawah sebesar $34,48 \%$, tambak sebesar $2,75 \%$, kebun campuran sebesar $2,03 \%$, dan hutan sebesar $0,2 \%$, serta meningkatnya kawasan terbangun sebesar $39,47 \%$. Faktor yang mempengaruhi perubahan penggunaan lahan, antara lain arah kebijakan pengembangan wilayah Kecamatan Pamanukan.

Perubahan penggunaan lahan pertanian di Kecamatan Pamanukan menyebabkan:

1. Perubahan struktur mata pencaharian rumah tangga petani dari sektor primer (pertanian) menjadi ke sektor sekunder dan tersier (buruh, pengrajin, PNS/TNI/POLRI, dan pedagang).

2. Jumlah petani pemilik lahan pertanian lebih kecil daripada jumlah petani non pemilik dengan perbandingan 1:5.

3. Penyusutan luasan kepemilikan lahan pertanian menyebabkan kenaikan migrasi keluar dengan tujuan mencari pekerjaan (sebagai TKI dan buruh bangunan di Jakarta dan Bekasi).

\section{DAFTAR PUSTAKA}

Anonim (2000). Data Isian Profil Desa Se-Kecamatan Pamanukan Tahun 2000.

Anonim (2006). Data Isian Profil Desa Se-Kecamatan Pamanukan Tahun 2006.

Anonim (1998). Rencana Detail Tata Ruang Kota Pamanukan Tahun 1997-2012. 
Linda Dwi Rohmadiani : Dampak Konservasi Lahan Pertanian Terhadap Kondisi Sosial Ekonomi Petani

Anonim (2001). Rencana Tata Ruang Wilayah Kabupaten Subang Tahun 2001-2011.

Anwar, Effendi (1993) Dampak Alih Fungsi Lahan Sawah Menjadi Lahan Non-Pertanian Di Sekitar Wilayah Perkotaan, Jurnal Perencanaan Wilayah Dan Kota, ITB, No. 10/Desember

Badan Pusat Statistik Kabupaten Subang. (1997), Kabupateng Subang Dalam Angka Tahun 1997.

Badan Pusat Statistik Kabupaten Subang. (2001), Kabupateng Subang Dalam Angka Tahun 2001.

Badan Pusat Statistik Kabupaten Subang. (2002), Kabupateng Subang Dalam Angka Tahun 2002.

Badan Pusat Statistik Kabupaten Subang. (2003), Kabupateng Subang Dalam Angka Tahun 2003.

Badan Pusat Statistik Kabupaten Subang. (2004), Kabupateng Subang Dalam Angka Tahun 2004.

Edrijani (1994), Alih Fungsi Lahan Dan Marjinalisasi Di Wilayah Jalur Bandung-Soreang, Tugas Akhir Pada Jurusan Teknik Planologi, ITB.

Fauzia, Lily (2007) Pengaruh Alih Fungsi Lahan Pertanian Terhadap Sosial Ekonomi Pertanian. Tesis. Universitas Sumatera Utara Medan.

Kustiwan, Iwan (1996), Kajian Permasalahan Dan Kebijaksanaan Pengendalian Konversi Lahan Pertanian Di Wilayah Pantai Utara Pula Jawa, Tesis Pada Program Magister Studi Pembangunan, ITB

Pasaribu, Sahat M., Reni Kustiari, dan Waluyo (2000) Arah Dan Pola Migrasi Tenaga Kerja Di Pedesaan, Makalah Pada Prosiding Penetian Sosial Ekonomi Pertanian IPB

Saefulhakim, R.S. dan L.I. Nasoetion (1996), Kebijaksanaan Pengendalian Konversi Sawah Beririgasi Teknis. Makalah Pada Prosiding No. 12 Penetian Tanah IPB 